\title{
A Question of Trust: the Pursuit of Consumer Trust in the Financial Sector by Means of EU Legislation
}

\author{
C. E. de Jager ${ }^{1}$
}

Received: 26 April 2016 / Accepted: 12 September 2016 /

Published online: 8 October 2016

(C) The Author(s) 2016. This article is published with open access at Springerlink.com

\begin{abstract}
The decrease in consumer trust in the financial sector and the attempts to restore it are receiving a great deal of interest, especially since the financial crisis at the end of 2008. EU legislation is one of the ways that attempts have been made to regain the trust of investors. In the second section, the concept of "trust" will be subjected to an in-depth yet not exhaustive examination, with the aim of reducing its elusiveness. The third section will discuss three recent EU proposals. Examination of these legislative proposals reveals that (1) the term "trust" is not precisely defined, and (2) without stating further reasons, the restoration of trust in the financial sector is considered a worthy goal. In light of the aforementioned, the fourth section will address the desirability of clarity regarding the term "trust." The fifth section will then assess whether legislation is a suitable means to restore consumer trust, and the sixth section explores whether the restoration of consumer trust in the financial sector is a worthy goal. Indeed, the European legislator and other policymakers seem to consider a low level of consumer trust a bad thing, a high level of consumer trust a good thing, and a higher level of consumer trust an even better thing. This article will argue that it is doubtful whether EU legislation is a suitable means for restoring consumer trust in the financial sector and, moreover, that considering the perverse incentives in the current financial sector, among other things, a realistic degree of trust, implying a certain distrust, appears preferable.
\end{abstract}

Keywords Trust · Financial markets · Financial sector · Consumer protection · Financial crisis · European legislation

This article is partly based on an article published in the Dutch journal THEMIS (De Jager, C.E. (2015). De financiële sector: weg (van) vertrouwen of op weg naar vertrouwen? Over het nastreven van consumentenvertrouwen in de financiële sector door middel van EU wetgeving na de financiële crisis. Rechtsgeleerd Magazijn Themis, 6, 244-257). This research is funded by a NWO Research Talent Grant (406-12-144).

C. E. de Jager

c.e.de.jager@rug.nl

1 Department of Private Law and Notary Law, University of Groningen, Groningen, The Netherlands 


\section{Introduction}

"How we can restore trust in financial institutions," "Rock-bottom - that's where trust in financial services is," "Barclays boss admits it could take 10 years to rebuild public trust," and 'Banks must 'raise their game' to win back public trust' (respectively Brown 2009; Hargreaves 2007; Monaghan 2013; Trotman 2015). These are just a few news headlines from recent years. The decrease in consumer trust ${ }^{1}$ in the financial sector and the attempts to restore it are receiving a great deal of interest, especially since the financial crisis in late $2008 .{ }^{2} \mathrm{EU}$ legislation is one of the ways in which attempts are being made to regain the trust of investors. The focus in this article is on retail investors (consumers) on the market for investment products $^{3}$; however, considerable parts also apply to the financial market as a whole. It is also worth mentioning that this article will not go into much detail on the role of trust in the 2008 financial crisis because this has already been discussed a lot in the literature (see, e.g., Georgarakos and Pasini 2011; Sapienza and Zingales 2012, p. 723; Zingales 2011; and on the role of information, contracts, and regulation in the 2008 financial crisis: Diamond and Dybvig 1983; Tonkiss 2009).

In the second section, the concept of "trust" will be subjected to an in-depth yet not exhaustive examination, with the aim of reducing its elusiveness. The third section will discuss three recent EU proposals. Examination of these legislative proposals reveals that (1) the term 'trust' is not precisely defined, and (2) without stating further reasons, the restoration of trust in the financial sector is considered to be a worthy goal. In light of the above, the fourth section will address the desirability of clarity regarding the term "trust." Next, the fifth section will assess whether legislation is a suitable means when it comes to restoring consumer trust. However, whether the content of the proposed regulation (e.g., information duties or the remedies available to an investor against breaches of standards of conduct by the provider in contract or tort law) is likely to be effective in restoring trust, falls outside the scope of this article, since this is discussed by others (see, e.g., Guiso 2010; Springford 2011) and is an almost impossible question to answer based on literature because it depends greatly on the specific circumstances and future developments. Finally, the sixth section explores whether the restoration of consumer trust in the financial sector is a worthy goal. Indeed, the European legislator and other policymakers seem to consider a low level of consumer trust as a bad thing, a high level of consumer trust as a good thing, and a higher level of consumer trust an even better thing. ${ }^{4}$ This article will argue that it is doubtful whether EU legislation is a suitable

\footnotetext{
${ }^{1}$ Trust has to be distinguished from confidence, although in many languages the same word is used for both concepts, such as "vertrouwen" in Dutch and "Vertrauen" in German. Confidence is the optimism or pessimism about the future (e.g., consumer confidence in the economic policy of the government or personal finances). Trust has a concrete object (for example a bank or a financial advisor). See about the difference between trust and confidence Van Esterik-Plasmeijer and Van Raaij 2012, pp. 1-2. Strikingly, the European legislator does not seem to make a clear distinction between "trust" and "confidence."

${ }^{2}$ As evidenced by for instance the congresses being organized and various research projects conducted, such as on a European level a conference of the European Securities and Markets Authority on "Restoring investors" trust in Europe's markets (European Securities and Markets Authority 2012) and, UK reports, e.g., (The Social Market Foundation 2011; Chater and Decision Technology Limited 2015).

${ }^{3}$ On the other hand, business-to-business relationships and trust among nations fall outside the scope of this article. For a comprehensive overview of those relationships, see respectively Chowdhury (2012) and Bottazzi et al. (2016).

4 Indeed, this is not only the European legislator's opinion. For instance, the chair of the European Securities and Markets Authority states "It is also clear that to let our economies grow again and to move out of the current difficult economic phase, investor trust needs to be restored" (Maijoor 2012).
} 
means for restoring consumer trust in the financial sector and, moreover, that considering the perverse incentives in the current financial sector, among other things, a realistic degree of trust, implying a certain distrust, appears to be more desirable.

\section{The Concept of "Trust"}

In a now well-known metaphor, the philosopher Baier illustrated the elusiveness of trust by comparing it to clean air (Baier 1986, p. 234). We live in a trust-filled environment the same way that we live in an environment with clean air. Only when it gets difficult for us to breathe and the air is polluted do we notice that we are breathing air. The same goes for trust: we only become aware of it if it is under pressure or if it is not there. In the following, an attempt will be made somewhat to reduce the elusiveness of the concept of trust. It must be noted, however, that this will not include a full summary or the formulation of a definition of trust. ${ }^{5}$

Researchers of various branches of science have paid a great deal of attention to trust, resulting in a kaleidoscopic image (Nooteboom 2002b, p. 19): the perspective from which the concept is viewed determines what is seen. ${ }^{6}$ Economists view trust mainly as the lubricating oil of the financial market, in the sense that it helps achieve economic goals, reduce transaction costs, and increase efficiency (Knack 2001; Knack and Keefer 1997, pp. 1251-1252; Temple and Johnson 1998, pp. 987-988; Zak and Knack 2001, pp. 295-296). ${ }^{7}$ According to social psychologists, trust is rather a sense of goodwill toward others, which is important for many things, including cooperation. ${ }^{8}$ In contrast, sociologists and political scientists consider trust to be the basis for social capital. ${ }^{9}$ As for the mechanisms behind trust, neurologists study the connections in our brains and emphasize that feelings and behaviour related to trust can be learned, while biologists claim that trust is determined, for instance, by hormones and the environment in which people grow up. ${ }^{10}$

\section{Four Elements}

In spite of the wide diversity of definitions and insights, ${ }^{11}$ it is generally assumed that trust consists of four elements, which are connected in the following way: $I$ trust you regarding $x$ in certain circumstances. Thus there is, first, a subject that trusts (“ $P$ ”), which in principle, is a person (Liebsch 2010, p. 185). Many authors point out that some people are more trusting than others (Berg et al. 1995; Evans and Krueger 2009, pp. 1010-1011). These differences are in part predicted (and perhaps caused) by an underlying propensity to trust (Evans and Krueger

\footnotetext{
${ }^{5}$ The subject of "self-interest" will not be discussed, and neither will the question whether altruism exists, and whether it would be a good thing if it did. For such questions, see Nooteboom (2002a, pp. 47-49 and 72-74). For a survey of trust, see also Nooteboom (2002a, b).

${ }^{6}$ For this overview, among others, Voortman (2012, pp. 25-37) was used.

${ }^{7}$ Nevertheless, few studies are known about the relationship between an individual's trust levels and its influence on his or her economic situation, see also Butler et al. (2009), p. 1.

${ }^{8}$ See, e.g., Jones and George (1998), about the role of cooperation in an organization.

9 Sobel (2002, p. 139) defines social capital as follows: "social capital describes circumstances in which individuals can use membership in groups and networks to secure benefits." See also Arrow (1999, pp. 3-5).

${ }^{10}$ For the possible effects of the hormone oxytocin on trust, see, e.g., Zhong et al. (2012).

11 This is one of the reasons why this article does not attempt to formulate a specific definition of trust. Many such attempts have been made already, see, e.g., Nooteboom (2006, p. 252).
} 
2009; Rotter 1967). As mentioned earlier, the focus in this article is on consumers on the market for investment products.

Second, the subject trusts something (you), being the object of trust. Among other things, this could be a person, organization, system, or thing (Nooteboom 2002a, p. 8). ${ }^{12}$ There can be multiple levels of trust (e.g., Nooteboom 2002a, pp. 54-61). Indeed, on the financial market, there are at least three levels of trust: the financial market as a whole, financial institutions (such as banks), and people working at those financial institutions. Accordingly, buying an investment product requires trust in the functioning of the financial markets, in the financial institution offering the product, and in the people working in these institutions. Trust in these objects is closely interrelated. For example, whether a banker can fulfil his or her commitments depends on the interests of the financial institution and common practices within the organization. Furthermore, his or her behaviour will be influenced by incentives on the financial markets (see in more detail "Trust as a Goal of Legislation"). Conversely, trust in financial institutions is influenced by trust in the people working in those particular institutions. The multiple levels of trust can also be illustrated by the financial crisis in 2008. This crisis has caused distrust of bankers (persons) because of greed for money and acting in their own interests instead of acting in their clients' best interests. This behaviour was and still is caused by perverse incentives within financial institutions and the financial markets, such as a strong preference for short-term profit, neglecting risks in the long run. Since trust in these objects is closely interrelated, they will be all taken into account in this article and could not always be clearly separated.

Third, we have trust in, for instance, the competence or intention of the object (" $x$ ") (Prast et al. 2005, p. 25). ${ }^{13}$ This is a very relevant factor because the actions of the object of trust and the outcomes of these actions entail a number of other causes, which could be referred to as "multiple causality" (Nooteboom 2002a, p. 50). One of the causes is the competence a person needs to achieve an expected level of performance, such as abilities, skills, and knowledge. Furthermore, the person also needs to trust the materials used by the object, the aims of the object, his or her intentions, dedication, care, benevolence, goodwill, and truthfulness (Nooteboom 2002a, pp. 50-54). The distinction between these causes (which are in fact also objects of trust) are important, because it could clarify why people should or should not trust an object, and it could help in deciding which (policy) response is the most appropriate. For example, a lack of competence could be improved by training. If opportunism is the problem, we may consider penalties, replacement, or an appeal to ethical behaviour.

Lastly, the level of trust depends on the circumstances and the context ("circumstances") (Nooteboom 2010, p. 27). As mentioned earlier, how much someone trusts a banker is partly determined by how much this person trusts banks and the financial sector as a whole, and circumstances can lead to someone being trusted experiencing incentives to be opportunistic. ${ }^{14}$ For example, in an environment where money plays an important role, people tend to be more self-focused and less likely to help others (Vohs et al. 2006). This is in line with Heymann and Ariely (2004) who note that whereas monetary markets encourage quid pro quo behaviour, social markets inspire less calculated acts of reciprocity.

\footnotetext{
12 Or, as (Dunn (2000, p. 81)) put it: “The twin of trust is betrayal." See also Liebsch (2010, p. 177), who states that in practice, things and social processes are reliable, meaning that there is no trust with regard to things and social processes.

${ }^{13}$ They further point out that this is also reflected in the supervisory policies of the Dutch central bank. On the objects of trust, see also Nooteboom (2006, pp. 248-249).

${ }^{14}$ Compare Nooteboom (2010, p. 27).
} 


\section{Trust and Reliability}

It is important to distinguish between trusting someone and relying on someone (Liebsch 2010, p. 177; Nooteboom 2010, p. 28). Indeed, you can rely on someone without trusting that person, a distinction which can be illustrated with the following example (Nooteboom 2010, p. 28). When a consumer takes out an insurance policy, he or she places his or her reliance in the insurance agent. This, however, does not imply that the insurance agent is actually trusted. In other words, one can rely on someone without trusting that person. In fact, there can be good reasons for expecting this insurance agent to behave predictably and consistently (i.e., to rely on this insurance agent), but naturally this is not indicative of whether he is worthy of this reliance and can therefore be trusted. It must be added that the distinction between reliance and trust is not a clear-cut one. After all, how much someone relies on someone else will affect the level of trust he or she is willing to put in this person. This further shows that trust is not an allor-nothing concept, but that it can be present to a greater or lesser degree (Nooteboom, p. 27).

According to Casson and Giusta (2006, p. 346), reliability or trustworthiness is an objective characteristic of an individual in a given type of situation, but it cannot be directly observed. Glaeser et al. (2000) conclude from the experiments they conducted that social connection strongly predicts trustworthiness (or in other words, whether someone is reliable) but weakly predicts trust. In particular, the study concludes that national and racial differences between partners strongly predict a tendency to cheat one another. The latter is especially relevant given the diversity in the European Union, for which the new financial legislation will come into force (see Restoring Trust by Means of EU Legislation section).

\section{Trust and Risk}

Related to this is another characteristic of trust, i.e., the uncertainty it entails: trust only exists where there is also a risk of it being betrayed (Ben-Ner and Putterman 2001, p. 530; Liebsch 2010 , p. 177). It is after all related to the (future) behaviour of another party and can therefore be seen as a fictional security while there is insecurity (Gärling et al., p. 30; Peperzak 2013, p. 18) ${ }^{15}$; or, formulated more concretely, trust transforms insecurity into risk (Luhmann 1979, p. 22). This is clearly reflected in the way Sobel defines trust, being a person's willingness to let his or her own well-being be determined by another person's decisions (Sobel 2002, p. 148). The more uncertainty there is, the more trust is required, but trust does not lead to a reduction in uncertainty, but rather to a greater acceptance of it (Sobel 2002, p. 148). Trust can thus at least partly act as compensation for a sense of uncertainty.

Empirical evidence, however, is mixed about the relationship between trust and risk. Fehr (2009) argues that trust is not a form of risk-taking, but based on important forms of social preferences such as betrayal aversion. Eckel and Wilson (2004) conclude that they found no statistical relationship between people's attitudes to risk and the decision to trust. All in all, the relationship between trust and risk or uncertainty is very complicated (for a more detailed exploration of this subject, see Nooteboom 2006, pp. 38-41). At the very least, trust entails some risk or uncertainty since we can never be completely certain about another's behaviour.

\footnotetext{
${ }^{15}$ Compare also the definitions formulated by Lewis and Weigert (1985, p. 969): "To trust is to live as if certain rationally possible futures will not occur"; and Mayer et al. (1995, p. 712) (which refers to Knee and Knox (1970): "[...] the willingness of a party to be vulnerable to the actions of another party based on the expectation that the other will perform a particular action important to the tractor, irrespective of the ability to monitor or control that other party."
} 


\section{The Importance of Trust}

The above could give rise to the question: Why do people trust when it involves such risk? In this context, the so-called value of trust is relevant. Trust can have both extrinsic and intrinsic value (Nooteboom 2006, pp. 252-253; Nooteboom 2002a, pp. 2-5) for a person. ${ }^{16}$

As an intrinsic value, trust can enhance the quality of our lives. For example, people reporting that they live in a trustworthy environment experience a greater sense of well-being (Helliwell and Wang 2010, p. 21). Trust has extrinsic value in that it can help us achieve social and economic goals. For example, financial products offer consumers the opportunity to do things they otherwise may be could not do, such as purchase a house.

Related to this, an important reason to trust more generally seems to be that it is often connected to the expectation of something positive or important for the one placing trust in the other party. ${ }^{17}$ The unpredictable behaviour of the other can lead to one of two results: a positive one or a negative one. ${ }^{18}$ If the trust was justified, a transaction could result in a higher yield than if no transaction had been involved (a positive result). However, if the trust is betrayed, the loss is often greater than the yield gained had the trust been justified (a negative result). Imagine a banker offering a consumer a financial product, with the promise of a $10 \%$ yield on his investment. ${ }^{19}$ If the consumer places his or her trust in the banker and invests EUR 1000 in the financial product in question, this should yield a financial profit of EUR 100. However, if the banker turns out to be untrustworthy, the consumer could then lose the entire investment (EUR 1000). As Liebsch (2010, p. 189) powerfully summarizes: "It is, to be sure, a one-sided, asymmetric 'investment,' which makes, as such, no 'economic' sense."

From a societal point of view (which could be categorized as the "extrinsic value of trust"), trust is relevant for the effective functioning of the economy. According to Arrow (1972, p. 357), virtually every commercial transaction has within it an element of trust. Several studies reveal a positive relationship between trust and economic performance or point out, conversely, that a lack of trust can have various drawbacks (e.g., Knack 2001; Knack and Keefer 1997, pp. 1251-1251; Temple and Johnson 1998, pp. 987-988; Zak and Knack 2001, pp. 295). Before providing a brief overview of the relationship between trust and economic outcomes documented in the existing literature, it must be noted that there are also concerns about the causal role of trust in economic (and social) transactions (Fehr 2009). Fehr (2009) argues, for example, that the identification of the exact role of trust in economic transactions has proven elusive. Other studies also dispute the positive link between trust and economic growth, for example Beugelsdijk and Schaik (2003) and Helliwell (1996).

Despite these concerns, most studies have shown that trust is an essential element for an economy to work. Using data from the World Values Survey for 29 market economies, Knack and Keefer (1997) conclude that trust positively correlates with economic performance because an increase of 1 standard deviation in country-level trust predicts an increase in Gross Domestic Product (GDP) of more than one half of a standard deviation. Approximately

\footnotetext{
${ }_{16}$ Blau distinguishes between the intrinsic and extrinsic value of social behaviour (Blau 1964, p. 100).

${ }^{17}$ A commonly used definition of trust is therefore: "To trust is to make yourself vulnerable to the actions of another party in the expectation that the other will perform a particular action which is important to you." (Six 2003, p. 199, which refers to Mayer et al. 1995, p. 712). Regarding this, Bhattacharya et al. (1998, p. 462) state: "Trust is an expectancy of positive (or nonnegative) outcomes that one can receive based on the expected action of another party in an interaction characterized by uncertainty."

${ }^{18}$ Also known as positive and negative risk, respectively (e.g., Mosch and Prast 2008, p. 19).

${ }^{19}$ Example partly taken from Mosch and Prast (2008, p. 19).
} 
10 years later, Dincer and Uslaner (2010) arrived at the same conclusion, i.e., that trust is related to higher GDP. Others highlight the importance of trust in the asset management industry, such as the relationship between investors and portfolio managers (Kostovetsky 2016). In addition, Guiso et al. (2004) show that Italian households invest higher amounts in financial assets when they live in regions with high trust rates. In instrumental terms, the resources of trust promote economic efficiency by reducing the transaction costs of economic exchange, on the assumption that others will behave according to common norms of economic conduct (Tonkiss 2009, p. 196). Finally, Knack (2001) provides arguments and evidence for the importance of high trust in the economic performance of nations.

From an economic point of view, a lack of trust could have negative consequences. Low confidence can turn into a self-fulfilling prophecy which causes an economic recession and puts currencies and payments at risk, for example leading to hyperinflation (Katona 1975). Furthermore, it turned out that low trust environments reduce the rate of (stock) investment (Guiso et al. 2008, p. 2557; Zak and Knack 2001, p. 295). ${ }^{20}$ However, the contribution of trust to stockholding seems to vary across different groups of households (Georgarakos and Pasini 2011).

Low levels of trust have also been studied since the financial crisis of 2008. For example, Zingales (2011) found that investors who plan to decrease their stock investments after the financial crisis are those who have less trust in financial markets and especially in the stock market. He also points out that trust can have important economic effects through additional channels. First, lack of trust affects the ability to experiment and learn. Second, a trusting attitude is self-fulfilling: the more we trust our partners, the more they behave in a trustworthy way and vice versa. Finally, trust can have important economic effects in a situation where multiple equilibria are possible and where the subjective component of trust can determine which equilibrium is selected.

\section{Sources of Trust and Reliability}

Regardless of the fact that, depending on circumstances, there are reasons to betray trust, in general there are various incentives encouraging someone not to do so.

At a macro (institutional) level, contracts, legal compulsion, incentives such as reputation, value, standards of good behaviour, sense of duty, and ties of kinship play a role (Nooteboom 2002a, pp. 63-66). ${ }^{21}$ At a micro (relational) level, the following reasons lead people to act reliably: hierarchy, administrative approval, incentives such as dependency, bonuses, empathy, identification, shared norms and values, habit, feelings, and friendship (Nooteboom 2002a, pp. 63-66). ${ }^{22}$ Thus, in summary, there are two instruments for promoting reliability: compulsion (such as legal compulsion or supervision) and incentives (such as reputation). ${ }^{23}$ In addition, norms, values, and empathy can be viewed as causes of reliability.

\footnotetext{
${ }^{20}$ Conversely, trust will only lead to a greater willingness to invest money.

${ }^{21}$ Nooteboom shows on page 63 that he borrowed this distinction from Williams (1988).

22 There is an overlap between the micro and macro levels. Nevertheless, the distinction is useful in the context of the financial sector, since it involves the relationship with the customer (micro), as well as the institutional environment of, inter alia, financial institutions and the applicable legal rules (macro).

${ }^{23}$ This is, however, not a clear-cut distinction since compulsion can also be viewed as an incentive. In addition, Nooteboom (2010, p. 30) defines compulsion as a restriction of an individual's scope of action. In my opinion, this is incorrect. After all, despite the fact that theft is considered to be an offense in Art. 310 of the Dutch Criminal Code and therefore could lead to legal repercussions, this does not restrict one's actual scope of action, since it is still possible to steal. Naturally, this does not have to be the case with physical compulsion, but Nooteboom does not appear to refer to that.
} 


\section{Two Sources of Trust and Reliability: Contracts and Regulation}

As mentioned in the previous subsection, contracts and regulation could be incentives for improving trust and reliability. Since this article focuses on improving trust by means of EU legislation, it is worth providing a brief overview of the existing literature on the role of contracts and regulation in improving trust.

Many scholars in sociology of law are sceptical about the role the legal system can play in supporting trust (Deakin 2006, p. 218). A widely held view in this field is that legal rules and sanctions are marginal to contractual relations. This opinion is based on empirical studies interpreted as showing that parties to business transactions rely mostly on informal norms and "trust" instead of contract law or formal agreements (Beale and Dugdale 1975; Collins 2002: ch. 6; Macaulay 1963).

Against this, many authors see contracts and law as important "mechanisms" for improving trust and trustworthiness (Prast et al. 2005, p. 26). First, regulation or entering into a contract can be a substitute for trust in the sense that it reduces the amount of trust needed (Nooteboom 2006, pp. 257-258; Simpson and Eriksson 2009, p. 63; Tonkiss 2009). In contrast, contracts and trust are constitutive (Nooteboom 2006, pp. 257-258). Some examples can illustrate this. First, because interactions typically cannot foresee all possible contingencies, most contracts are incomplete and as a result difficult to enforce (Bohnet et al. 2001; Engle-Warnick and Slonim 2004). Furthermore, there is a risk in accepting the contract due to incomplete information about, e.g., the seller, which requires trust and may partly be reduced by reputation (Göran and Hägg 1994). In addition, when the trustee fails to fulfil its obligations, the state could support trust and trustworthy behaviour through regulatory legislation (e.g., to cover losses) and supervision. Of course, this presupposes that the state, financial and other supervisors, and the legal system have earned a reputation as trustworthy in the eyes of citizens (Göran and Hägg 1994, p. 447).

Many studies suggest that contracts and regulation are positively related to trust and trustworthiness. Knack and Keefer (1997) and Zak and Knack (2001) present cross-country evidence showing that governmental mechanisms for the effective enforcement of contracts are associated with greater trust. However, it must be noted that the causality of this link could be questioned because causality can easily go in both directions in such relationships (Knack 2001, p. 4). Malhotra and Murnighan (2002) show that in a trust game, trustees send more to their "counterpart" when the trustor agreed to a non-binding contract. Furthermore, the legal system generates incentives for parties to uphold contracts in the form of fines and recognisances and is therefore an important mechanism to reduce transaction risks.

On the other hand, contracts and regulation could also have some drawbacks. As regards contracts, it should first be noted that incomplete information and low financial literacy lead to incomplete and poorly understood contracts (Mosch and Prast 2008, pp. 22-23). This happened during the 2008 collapse of the subprime mortgage market in the USA and elsewhere. For a contract to be effective, it is important that its content is well understood by both parties and based on relevant information (which was often not the case in the subprime mortgage market: Tonkiss 2009, p. 199). Furthermore, it seems that contracts can injure the intrinsic motivators of trust and trustworthiness (Bohnet et al. 2001; Fehr and Rockenbach 2003; Malhotra and Murnighan 2002; Mulder et al. 2006; Simpson and Eriksson 2009). The study of Ben-Ner and Putterman (2009) is also relevant in this context. They studied a one-shot trust game with the opportunities to engage in pre-play communication and to enter binding and non-binding contracts. They found that contracts are largely unnecessary for trusting and 
trustworthy behaviours and were eschewed by many players. Moreover, legal procedures for enforcing contracts tend to be expensive.

Similarly, regulation is not always positively related to trust and trustworthy behaviour. Evidence from cross-country correlations shows that countries with stronger regulation have lower average levels of trust instead of higher (Aghion et al. 2009; Carlin et al. 2009; Pinotti 2008). This is in line with Guiso (2010, pp. 14-15), who clarifies that the proportion of people supporting more stringent regulation is higher among those whose trust fell during the crisis than among those who continue to trust banks and financial markets. Government regulation seems also strongly negatively related to social capital (Aghion et al. 2009). In this context, Carlin et al. (2009) distinguish between valuable and less valuable social capital in their attempt to analyse the optimal level of regulation. They conclude that where social capital is valuable, regulation and trustfulness are substitutes. In this situation, regulation can cause lower aggregate investment and decreased economic growth. However, when social capital is less valuable, regulation and trustfulness may be complements.

\section{Causal Ambiguity}

Trust is often accompanied by causal ambiguity, meaning that it is often hard to determine what exactly caused the failure to achieve a certain result. ${ }^{24}$ For instance, if a consumer has invested money in a complex financial product which, in the end, yields a lower profit than expected, this could then be caused by many things, such as an error or circumstance that nobody could prevent, the people investing the money being incompetent or opportunistic, a lack of research into the product by the investor, incorrect or incomplete information from the financial advisor, conjunctural developments, a lack of competence on the part of the advisor who recommended the product, etc. ${ }^{25}$ The specific characteristics of the financial sector, which "Trust in the Financial Sector: Legislation as a Means" and "Trust as a Goal of Legislation" sections will consider more closely, entail a great degree of causal ambiguity for investors. However, the next section is about the attempts of the EU legislator to restore consumer trust in the financial markets.

\section{Restoring Trust by Means of EU Legislation}

Legally, the financial crisis started two movements: one in the area of litigation and the other in the area of legislation. ${ }^{26}$ In the area of litigation, compensation is claimed for people who suffered losses due to risky financial products and fraud. Well-known examples include the Bernard Madoff Lawsuit in the USA and numerous scandals concerning profiteering policies and margin lending. ${ }^{27}$ At the same time, in the area of legislation, various attempts are being made to prevent the recurrence of such situations in the future and to restore the trust that was lost. In this context, three EU

\footnotetext{
${ }^{24}$ Nooteboom (2009, pp. 35-36) and Nooteboom (2002a, pp. 49-54) on the causes of failure and the failure of causes.

${ }^{25}$ Indeed, the same applies when a financial product does yield the expected profit or even a higher one, although the question of what caused this usually will be less pressing.

${ }^{26}$ In this context, reference should also be made to self-regulation in the financial sector. Cf. infra, note 70 .

${ }^{27}$ Such as the Woekerpolis and Effectenleaseaffaire in the Netherlands and the miss-selling of Payment Protection Insurance (PPI) in the UK. See, e.g., Judgment of the Court (CJEU) of 29 April 2015 in Case C-51/13 Nationale-Nederlanden Levensverzekering Mij v. Van Leeuwen, ECLI:EU:C:2015:286.
} 
legislative proposals will be discussed successively: the introduction of a new pre-contractual information document for complex financial products, ${ }^{28}$ MiFID II (MiFID stands for Markets in Financial Instruments Directive) ${ }^{29}$ and the Mortgage Credit Directive. ${ }^{30}$ These European legislative proposals are for illustrative purposes only, since this article does not provide enough room for a detailed examination of the likely effectiveness in increasing trust in them.

The first example is a Regulation stating that, as of December 2016, providers of complex financial products ${ }^{31}$ must provide consumers with a short information document - a Key Information Document - in the pre-contractual phase. ${ }^{32}$ This document should include information regarding the costs and risks associated with a financial product. ${ }^{33}$ The Regulation is part of a larger legislative package aiming to restore consumer trust in the financial sector. ${ }^{34}$

In the explanatory memorandum to the proposal, it is established that retail investors have lost money on investments in which the risks were unclear or difficult to understand. Next, it concludes $^{35}$ :

This is in a context where investor confidence has collapsed: a recent survey of consumers across the $\mathrm{EU}^{36}$ showed they trust the financial services less than all other industry sectors. Rebuilding confidence on a sound basis is vital. Improving provisions on transparency so that they work in favour or retail investors, taking into account their needs is a vital component of this.

A second Directive ${ }^{37}$ and Regulation ${ }^{38}$ serving to increase consumers trust in the financial sector is MiFID II. The financial crisis brought to light that the first MiFID Directive ${ }^{39}$ had various shortcomings with regard to the operation and transparency of the financial markets. ${ }^{40}$

\footnotetext{
${ }^{28}$ Regulation (EU) No 1286 of the European Parliament and of the Council of 26 November 2014 on key information documents for packaged retail and insurance-based investment products (PRIIPs), OJ L 3521/1 of 9 December 2014. See about this Directive, (De Jager 2015).

${ }^{29}$ Directive 2014/65/EU of the European Parliament and of the Council of 15 May 2014 on markets in financial instruments and amending Directive 2002/92/EC and Directive 2011/61/EU, OJ L 173/84 of 12 June 2014; and Regulation (EU) No 600/2014 of the European Parliament and of the Council of 15 May 2014 on markets in financial instruments and amending Regulation (EU) No 648/2012, OJ L 173/84 of 12 June 2014.

${ }^{30}$ Directive 2014/17/EU of the European Parliament and of the Council of 4 February 2014 on credit agreements for consumers relating to residential immovable property and amending Directives 2008/48/EC and 2013/36/EU and Regulation (EU) No 1093/2010, OJ L 60/34 of 28 February 2014. For more general information about the development of measures for the protection of investors at a European level see, e.g., (Moloney 2005, pp. 352354).

${ }^{31}$ Packaged Retail Investment and Insurance Products (PRIIPs).

32 Regulation (EU) No 1286 of the European Parliament and of the Council of 26 November 2014 on key information documents for packaged retail and insurance-based investment products (PRIIPs), OJ L 3521/1 of 9 December 2014. For an overview of this Directive, see De Jager (2015, pp. 102-105).

${ }^{33}$ For a comprehensive exploration of the likely effectiveness of this information document, see De Jager (2015, pp. 105-118).

34 The legislation package contains two additional parts, being a revision of Directive 2002/92/EC and a revision of Directive 2009/65/EC. The goals of these revisions are better protection of customers buying insurance products and a strengthening of the function of depositaries for institutions in collective investment institutions.

${ }^{35}$ European Commission, Proposal for a Regulation of the European Parliament and of the Council on key information documents for investment products, Strasbourg: 3 July 2012, COM(2012) 352 final, Explanatory Memorandum, p. 2. The Staff Working Document of the European Commission (2012, p. 3) states: "Improving transparency is vital to rebuild confidence on a sound basis." Compare also Regulation (EU) No 1286/2014, in particular recitals 2,28 and 40 .

${ }^{36}$ Unfortunately, a reference to the survey in question is lacking.

${ }^{37}$ Directive 2014/65/EU.

${ }^{38}$ Regulation (EU) No. 600/2014.

${ }^{39}$ Directive 2004/39/EC.

${ }^{40}$ Directive 2014/65/EU, recital 4.
} 
The aims of the new legislative package are to (a) strengthen the supervisory and regulatory framework for markets in financial instruments in order to promote transparency, protection of investors, and trust and (b) improve the functioning of the internal market in financial instruments. ${ }^{41}$ This should be achieved by measures including new and more stringent rules of conduct for investment firms, transparency requirements concerning stock market trading, a more stringent sanctions regime, and a more extensive set of instruments for regulatory authorities to work with.

As a final example, reference is made to the Mortgage Credit Directive, which can be viewed as a reaction to the problems on the home loan market. ${ }^{42}$ In fact, in the last few years consumers increasingly appear to encounter problems when it comes to paying off their mortgages. To illustrate: in the period from 1 October 2012 to 1 April 2015, the number of consumers with mortgage arrears in the Netherlands increased by more than 40,000 (BKR 2014, 2015). ${ }^{43}$ In this context, irresponsible lending and borrowing practices are regarded as an important factor leading to the credit crunch, since they caused consumers to lose faith in the financial sector. ${ }^{44}$ One of the aims of the Mortgage Credit Directive is therefore to bring about an efficient and competitive single market ${ }^{45}$ with a high degree of protection for the consumer by increasing consumer trust, among other things. ${ }^{46}$ To achieve this, lenders and credit intermediaries should adhere to a certain code of conduct when lending to consumers (art. 7) as well as meeting a number of minimum competence requirements (art. 9).

The various proposals all appear to be based upon one and the same argument. First, it has been established that the credit crunch brought to light certain problems regarding the financial sector. These problems, including a lack of transparency, have caused consumers to suffer damages and lose trust in the financial sector. ${ }^{47}$ Since trust in the financial sector is deemed desirable, legislation was used in order to restore it. Strikingly, in some proposals, such as the Mortgage Credit Directive, consumer trust is actually used as a means to achieve another goal, an efficient single market. ${ }^{48}$

\footnotetext{
$\overline{{ }^{41} \text { Directive 2014/65/EU, recital } 4}$ and Regulation (EU) No. 600/2014, recitals 1 and 5.

42 Directive 2014/17/EU of the European Parliament and of the Council of 4 February 2014 on credit agreements for consumers relating to residential immovable property and amending Directives 2008/48/EC and 2013/36/EU and Regulation (EU) No. 1093/2010, OJ L60/34 of 28 February 2014; European Commission, Proposal for a Directive of the European Parliament and of the Council on credit agreements relating to residential property, Brussels: 31 March 2011 COM(2011) 142 final. For a brief examination of this Directive and how it influences the responsible lending policies in the UK and the Netherlands, see Mak (2015, pp. 411-430).

${ }^{43}$ An increase of 19,445 consumers in the period 1 October 2012 until 1 October 2013, an increase of 16,942 in the period of 1 October 2013 until 1 October 2014, and an increase of 3927 in the period 1 October 2015 until 1 October 2015. That makes a total of almost 113,000 consumers having difficulty paying their mortgages in the Netherlands. Strikingly, in the period 1 April 2015 until 1 October 2015, the number of people with mortgage arrears in the Netherland decreased by 119 , the first decrease in 10 years.

${ }^{44}$ Directive 2014/17/EU, recital 3.

45 This is a another commonly used term for the European internal market.

${ }^{46}$ Directive 2014/17/EU, recital 3. See also the explanatory notes on European Commission, Proposal for a Directive of the European Parliament and of the Council on credit agreements relating to residential property, Brussels: 31 March 2011 COM(2011) 142 final, p. 2.

${ }^{47}$ It should be noted that others, including Nobel Prize Laureate and economist Stiglitz, argue that it was in fact a sharp decrease in consumer trust which caused the financial crisis (Stiglitz 2008).

${ }^{48}$ The other two proposals described implicitly suggest this as well: see Directive 2014/65/EU, recital 3; European Commission, Proposal for a Regulation of the European Parliament and of the Council on key information documents for investment products, Strasbourg: 3 July 2012, COM(2012) 352 final, explanatory memorandum, p. 6. More recently, the creation of one European "rulebook" applying to every financial institution is considered to be an important goal of a large part of European financial legislation, see, e.g., Directive 2014/65/EU, recital 6.
} 
What exactly the European legislator means by (consumer) trust is not explained in the proposals. Therefore, in addition to providing some reflections on this, the next section will argue that, within this context, some clarification regarding the term "trust" is desirable.

\section{Trust: the Importance of a Closer Look}

As "The Concept of 'Trust"" section already pointed out, the concept of trust is hard to define. There is no uniform definition, and every area of science perceives it differently. ${ }^{49}$ Partly as a result of this, there are many misunderstandings surrounding the concept of trust (Fehr 2009; Glaeser et al. 2000, p. 815; Nooteboom 2002a, p. 1). However, it is in fact because of its versatility that exploration of this concept is recommended, since ambiguity regarding the meaning of trust (1) renders much empirical research, research to which the European Commission also refers unusable; and (2) leads to trust as the goal of legislation being a malleable concept and therefore not very meaningful. Both points will be addressed below.

\section{Unusable Research}

Nooteboom and others point out that confusion surrounding the concept of trust has rendered much empirical research useless, ${ }^{50}$ since its various distinctions and misunderstandings receive insufficient attention (Nooteboom 2010, p. 29; Nooteboom 2006, pp. 247-248; Fehr 2009; Glaeser et al. 2000, p. 815). ${ }^{51}$ In relation to this, Nooteboom (2010, p. 29) wonders: "If we have confidence in the police, does this mean that they are good at catching thieves or that they aren't corrupt?" 52 Confusion about the meaning of "trust" can cause problems for researchers, for instance when they need to draw conclusions on the basis of research results. Besides, if participants are asked as part of a study how much trust they have in a certain financial institution, then they will interpret the term "trust" in different ways according to their character, experience, the way the question is formulated, and their mood (Glaeser et al. 2000 , p. 815 ; Nooteboom 2010, p. 29). Moreover, if one study is based on a broad interpretation of the concept of trust, conclusions about "consumer trust being high" can be much more easily drawn than in another study based upon a more narrow definition of trust. Finally, an increase or decrease in consumer trust as compared to the results of research conducted for instance a year before is in practice not always an increase or decrease when the concept of trust is surrounded by confusion or when different definitions are used.

Therefore, when the European Commission writes that an EU-wide consumer survey shows that consumers put a lower degree of trust in financial services than in other industry sectors, this appears to be rather uninformative, in light of the aforementioned. ${ }^{53}$ Moreover, the fact that the European Commission does not refer to the location of the results of this survey

\footnotetext{
${ }^{49}$ For a comprehensive overview, see Voortman (2012, pp. 25-37).

${ }^{50}$ Indeed, Nooteboom calls such research invalid (Nooteboom 2006, p. 248).

${ }^{51}$ Nooteboom adds that he does not mean that those researchers are misleading the public on purpose, but, rather, that they do not have a clear understanding of the subject matter. I wholeheartedly agree with him on this.

52 Compare Nooteboom 2006, p. 261.

${ }^{53}$ European Commission, Proposal for a Regulation of the European Parliament and of the Council on key information documents for investment products, Strasbourg: 3 July 2012, COM(2012) 352 final, explanatory memorandum, p. 2.
} 
makes it impossible to determine how it was conducted and which definition of confidence it is based upon. ${ }^{54}$

\section{A Rather Meaningless Goal}

In addition to the above, the pursuit of consumer trust as a goal (or means) of EU legislation is rather meaningless if the concept of (consumer) trust is not clearly defined, thus giving rise to the question: "Trust in what way?"55 As the following will demonstrate, trust is a comprehensive concept which can be perceived in different ways, and uncertainty surrounding it can make evaluation of legislation aiming to restore it problematic. After all, even if there is a correlation between the requirements needing to be met under this legislation and consumer trust, then this does not necessarily mean that a causal link can be presumed. Therefore, when it comes to the evaluation of an act, how the concept of trust is operationalized will determine whether a guideline is successful. As a result of this "malleability," trust as a goal of legislation has little meaning. The aforementioned demonstrates the importance of a sound policy theory: the explicit or implicit assumptions underlying policy. ${ }^{56}$ Such a policy theory can be helpful to a policy researcher designing or evaluating policy (Hoogerwerf 1990, p. 285). Although a good policy theory evidently is no guarantee for a successful policy, it does increase the chances of it having the desired effects (Hoogerwerf 1990, p. 285). Unfortunately, the policy theory behind the EU proposals mentioned above is very weak, meaning that, at the very least, its effectiveness can be doubted.

\section{Trust in the Financial Sector: Legislation as a Means}

The EU uses legislation in order to restore consumer trust in the financial sector. ${ }^{57}$ It is, however, questionable whether such measures will have the desired effect, since "The Concept of "Trust" section shows that their proliferation could in fact be viewed as proof that trust in the financial sector is currently at a low level, given that it is the people who do not trust financial institutions who seem to be asking for more stringent regulations. ${ }^{58}$

According to Robert Reich (2008), an American economist and former United States Secretary of Labor, legislation is a suitable means for restoring trust in the financial sector: "If what's lacking is trust rather than capital, the most important steps policy-makers can take would be to rebuild trust. And the best way to do that is through regulations that require financial players to stand behind their promises and tell the truth, along with strict oversight to make sure they do." A standpoint that is easy to defend, it appears, since regulations which ultimately lead to protection of investors can at least potentially contribute to the regaining of trust.

\footnotetext{
${ }_{54}$ Since a reference is lacking, for instance it cannot be determined how trust was operationalized in this survey and which questions consumers had to answer.

55 That it essentially is also, or rather is used as, a means was already addressed above.

${ }^{56}$ Like the assumptions about the way in which a policy intervenes in the processes in the policy area. For more information about policy theory, see Hoogerwerf (1990), and on Impact Assessment in EU Lawmaking (Meuwese 2008).

${ }^{57}$ For standardization by means of goals, see, e.g., Westerman (2008, pp. 51-72), and for goal-regulation, Westerman (2007).

${ }^{58}$ According to Guiso, such measures appear to have little impact (Guiso 2010, pp. 14-15). See also Aghion et al. (2009).
} 
Reich's view is supported by several studies described in "The Concept of "Trust"" section which are clear that regulation could be an incentive for improving trust and reliability (e.g., Prast et al. 2005, p. 26). In fact, the legal system generates incentives for parties to uphold contracts through fines and recognisances, for instance. In this sense, a properly functioning legal system is an important mechanism to reduce transaction risks.

Nevertheless, "The Concept of "Trust"" section also points out that regulation could have some drawbacks. For example, legal procedures tend to be expensive. Therefore, transaction costs are minimized when economic business is done under an implicit rather than an explicit contract, without complicated legal forms to govern each agreement (e.g., Prast et al. 2005, pp. 26-27; Tonkiss 2009, pp. 196-197, and Ben-Ner and Putterman 2009 who provided laboratory evidence for this). In addition, many scholars seem to be sceptical about the role which the legal system can play in supporting trust and argue that parties mostly rely on informal norms instead of governmental regulation (Beale and Dugdale 1975; Collins 2002: ch. 6; Deakin 2006, p. 218; Macaulay 1963). Furthermore, research provides some evidence that countries with stronger regulation have lower average levels of trust (Aghion et al. 2009; Carlin et al. 2009; Guiso 2010; Pinotti 2008).

In sum, the existing literature is unclear about the exact role of regulation in improving trust and trustworthiness. However, based on the specific characteristics of the financial market, it is possible to approach this subject in another way and to provide arguments for the likely effectiveness of legislation as a means for improving consumer trust in the financial market. This will be done in the following subsections.

\section{Distance Between Legislator and Financial Sector}

First, in order to draft such legislation, there needs to be sufficient distance between the legislator and the financial sector (Tonkiss 2009, p. 201). However, when the legislation applies to banks that are "too big to fail," then this distance might be too small, since their going bankrupt or relocating could have disastrous economic consequences for a country. Here, two (public) interests appear to collide: (1) the promotion of a smooth functioning of the financial sector by means of legislation, ${ }^{59}$ and (2) the risk of a financial institution deeming this legislation undesirable to such a degree that it locates elsewhere, with negative consequences for the national economy. ${ }^{60}$ The lobbying power of the financial sector can be viewed as an indication of the distance between the legislator and the financial sector not being optimal. On 17 January 2015, in a letter to the editor, the Dutch Secretary of Finance Jeroen Dijsselbloem (2015) stated that the financial sector is trying to evade anti-crisis measures needed for a lasting recovery of the Dutch economy by using far-fetched and factually inaccurate arguments. He further wrote about an "enormous lobby" and "massive resistance" against, inter alia, capital adequacy requirements for banks and new solvency requirements for insurers.

\section{Legislation as a Determinant of Trust: One of Many, Not One in a Thousand}

The literature has addressed the question of how trust in a financial institution comes about and how, if needed, it can be restored, albeit in a limited way (Van der Cruijsen

\footnotetext{
59 Assuming that this is possible.

${ }^{60}$ Compare Luyendijk (2015, p. 183).
} 
et al. 2013, p. 2). ${ }^{61}$ Seven determinants of trust in financial service providers regularly emerge in varying orders of importance ${ }^{62}$ : competence, stability, integrity, good intentions and customer focus, transparency, value congruence, and reputation. According to Van Raaij, legislation is a means for enforcing integrity (Van Raaij 2009). ${ }^{63}$ However, regardless of the fact that consumers deem integrity important, according to Van Raaij they often experience it as being cool, bureaucratic, and formal. ${ }^{64}$ In addition, legislation can reinforce the other determinants. For instance, minimum competence requirements for lenders and credit intermediaries can lead to a better understanding of financial products as well as customers and their needs (competence), and the provision of a short information document about a financial product may increase transparency. ${ }^{65}$ On the other hand, from empirical research ${ }^{66}$, it can be gathered that high bonuses are the main reason why people have lost their trust in banks (Jansen et al. 2015). ${ }^{67}$ The question therefore remains whether the new legislation can counterbalance news items about, for instance, generous pay rises for board members of banks as compensation for the ban on bonuses (Deutsch and Neely 2014; Wallace 2015).

\section{Limited Effectiveness}

The Guidelines and Regulations include regulations imposed on the financial sector by external sources which therefore may meet with resistance from financial institutions. In connection to this, sometimes it is claimed that the undesirability of the costs that come with such measures could overshadow their potential benefits (Guiso 2010, p. 15). For financial institutions, this could be an incentive to evade the regulations resulting from this legislation to the greatest extent possible (Guiso 2010, p. 15). Or, in the words of a former banker: "No matter what rules you put in place, they'll always find ways around them.” (Luyendijk 2015, p.

\footnotetext{
${ }^{61}$ Studies regarding trust in the relationship between investors and financial advisors have only been examined to a limited degree as well, according to, e.g., Monti et al. (2014, p. 1749).

${ }^{62}$ Of the five determinants of Pirson and Malhotra (2008), Van Raaij used four which he expanded to seven and applied to the financial sector (Van Esterik-Plasmeijer and Van Raaij 2012; Van Raaij 2009, p. 19). In the Trust Compass study, only six determinants of trust were identified (Bol et al. 2014). Long-term research regarding empirical evidence for these determinants is needed, as is concluded by, e.g., Gärling et al. (2010, p. 31). However, these determinants are currently being used in studies regarding trust in the financial sector and therefore appear to have considerable practical use, for two Dutch examples, see, e.g., Bol et al. (2014). The determinants can further be distilled from research conducted by the Commissie (Commission) Maas (Maas et al. 2009). In addition, they are also mentioned by other authors, such as the determinants "ability," "benevolence," and "integrity" (Mayer et al. 1995, p. 715).

${ }^{63}$ Compare Westerman (2014), who claims that the "virtue" of integrity is brought up and praised when rules don't have the desired effects. Subsequently, this integrity is linked to protocols that can be qualified as goalregulation. On the likely effectiveness of informing consumers by means of an information document, see De Jager (2015, pp. 105-118).

${ }^{64}$ Indeed, I doubt whether it is integrity and not legislation and procedures which consumers experience as being cool, bureaucratic, and formal.

${ }^{65}$ Strikingly, a recent study on trust shows that, despite all of the attempts made by for instance the Dutch Financial Markets Authority to increase transparency in the financial markets, customers find financial institutions to be insufficiently open about, inter alia, the costs and risks associated with products and services (Bol et al. 2014, p. 49).

${ }^{66}$ As mentioned earlier, much empirical research is unusable on account of a lack of clarity regarding the concept of trust. Such research can, however, offer valuable insights into, for instance, the determinants and consequences of trust, which is the reason why this article does refer to various empirical studies. However, the studies referred to do not include surveys.

${ }^{67}$ Additionally, negative press releases, stock-market losses, and nontransparent product information are important factors (Jansen et al. 2015).
} 
169). ${ }^{68}$ Naturally, the fact that rules are not always observed by everyone is not an argument against rules, such as the described EU legislation. ${ }^{69}$ The expected effectiveness of such legislation can, however, be called into question. ${ }^{70}$

\section{Investor Interests}

In addition, investors can perceive measures aiming to protect them to be such a nuisance, that they will probably not object to a financial institution not applying the rules in an entirely correct way. For example, according to both the "new" and the "old" MiFID, banks should classify investors based on their ability to take financial decisions as well as their degree of risk tolerance. ${ }^{71}$ In order to do so, banks can ask their clients for information by means of, for instance, a questionnaire. The drafting, sending, and interpreting of such questionnaires costs time and money, meaning that there are incentives for banks to keep them short and to let investors categorize themselves. Since filling out such questionnaires will often be experienced as tedious by investors, they can be expected not to object too vehemently to such practices, with the result that, for instance, high-risk products, despite legal regulations, could still be sold to investors not wanting to take risks. In such cases, legal regulations do not appear to contribute to the restoration of consumer trust. On the contrary, seeing that communication plays an important role when it comes to trust (see $\S 4.2$ ), an investor could consider a short questionnaire to be a positive thing: "How considerate of the bank not to bother me with stacks of paperwork."

\section{Frustrating Goodwill}

Finally, flooding the financial sector with all sorts of obligations can actually put off those bankers who, in principle, wish to trade in a reliable way. ${ }^{72}$ As an obstetrician once said: "Well, you see, the problem is it takes longer to do the paperwork than to deliver the baby" (O'Neill 2013). Naturally, a banker works in a different work environment than an obstetrician, as will be seen in the following description of perverse incentives in the financial sector (\$4.2). In fact, these incentives could be an important reason for imposing such regulations on financial institutions. Nevertheless, there are people in the financial sector who do wish to give sound advice to consumers. If, as a result of legislation, these well-intentioned financial service providers choose to stop working in the financial sector and continue to work elsewhere, this can at least be considered an adverse side effect of these measures.

\footnotetext{
${ }^{68}$ Luyendijk (2015, p. 127) himself says that such new measures are symptomatic treatment: “[...] the regulatory response to the crash of 2008 has been to fight the symptoms instead of the cause," p. 127. See also, Jansen et al. (2015).

69 This could even be undesirable.

${ }^{70}$ In this context, it is sometimes claimed that self-regulation is the preferred option under certain circumstances. It must be noted, however, that, e.g., the Dutch Financial Markets Authority takes a critical stance toward selfregulation (The Dutch Financial Markets Authority 2011, p. 2). See on the efficiency of government regulation versus self-regulation (Westerman 2010) and on self-regulation on the Financial Markets: (Omarova 2010; Rawlings et al. 2014, pp. 29-31).

${ }^{71}$ Art. 25, Paragraph 2 MiFID II. This requirement is currently imposed by Art. 35 and 36 MiFID. Example taken from Guiso (2010), p. 16.

${ }^{72}$ For more general information, see O’Neill (2013).
} 


\section{Trust as a Goal of Legislation}

\section{Not "Trust," But "a Realistic Degree of Trust"}

After having discussed legislation as a means for restoring consumer trust, this article will now address consumer trust as a goal. As mentioned above, the new EU legislation is based on the assumption, without explaining why, that the restoration of trust in the financial sector is a worthy goal. The lack of such reasoning can possibly be explained by the "positive reflex" the concept of trust evokes: Trust is a good thing, right? It appears that the proverb good wine needs no bush is applied analogously to the pursuit of trust.

However, the decrease in consumer trust caused by bankers' fraudulent behaviour, for instance, can also be seen as proof that apparently too much trust was put in the financial sector. ${ }^{73}$ In other words, it turned out that bankers and financial institutions were less reliable than people thought them to be, and therefore deserved less trust because it became clear that a lot of them acted opportunistically and deceived investors. To clarify ${ }^{74}$ : in the years preceding the financial crisis, many people trusted Mr. Madoff with their money. Since Madoff took off with their savings, they lost trust in him. Now, should this trust be restored as quickly as possible? The answer seems obvious - it would not be desirable outcome, since too much trust was betrayed. More generally, this also applies to consumers' trust in the financial sector. In fact, it was actually the people who did have trust in the financial sector who invested their money and, as a result of that, are left with the most financial problems due to disappointing results and high residual debts.

In light of the aforementioned, the following will argue that the goal of the European legislator should not be so much a "restoration of trust," but rather a realistic degree of trust, implying a certain distrust. ${ }^{75}$ It is not possible to determine in absolute terms what exactly constitutes a realistic degree of trust, since this depends, as mentioned above, on four elements: the subject of trust, the object of trust, the competence or intention of the object, and the specific circumstances.

I should stress that I am not arguing that an absolute distrust with regard to the financial sector is recommended, nor that consumers, if this were even possible, should stay away from the financial markets, since trust is of value for consumers and is relevant for the functioning of the economy (as shown in "The Concept of "Trust"" section). In this context, I totally agree with Butler et al. (2009, p. 1) who state that it is important not to trust too much or too little. They conclude: "those who trust too little will give up trade and profit opportunities too often, depressing their economic performance; conversely, individuals who trust too much will overinvest in others and get cheated more frequently, hampering their economic outcomes."

This section is mainly based on the specific characteristics of the financial sector and insights about trust as described in "The Concept of "Trust" section. First, I will explain that there are many perverse incentives in the market for investment products which makes trusting significantly more risky than in other contexts ("Distance Between Legislator and Financial Sector" section). In addition, the fact that trust does not always mirror reliability ("Legislation as a Determinant of Trust: One of Many, Not One in a Thousand" section) and too much trust

\footnotetext{
${ }^{73}$ For that matter, there was also a crisis of trust among financial institutions themselves, see, e.g., (Guiso 2010, p. 2).

${ }^{74}$ Example taken from speech O’Neill (2013).

75 The philosopher more generally speaks of “intelligently placed and intelligently refused trust” (O’Neill 2013).
} 
can cause a chain reaction of distrust ("Limited Effectiveness" section), a realistic degree of trust seems to be better for consumers and the stability of the financial sector.

\section{Perverse Incentives}

As became clear in "The Concept of "Trust"" section, trust always involves some risk. However, this risk is much more prominent on the market for investment products than in other situations. Therefore, specific characteristics of the financial sector make a certain degree of distrust desirable, or as Peperzak (2013, p. 14) puts it: "[...] trust is preferable over distrust; but the circumstances [...] may make naive trust more pernicious than cautious distrust and intelligent lying." ${ }^{, 76}$ In the financial markets, these circumstances include so-called perverse incentives: "rewards" for undesirable behaviour. Some perverse incentives will be briefly described, mainly using a book published recently by Luyendijk (2015, but other authors also highlight these perverse incentives, e.g., Springford 2011). This book is an account of conversations Luyendijk - a journalist — had with about 200 employees and former employees in the City, Europe's financial centre in London. It offers unique insights into the financial world.

Examples A first perverse incentive is that complexity and a lack of transparency are rewarded (Luyendijk 2015, pp. 151, 175). Since complexity makes it difficult for consumers to compare financial service providers or financial products, they will be less inclined to switch financial institution. Second, people working in the financial sector can be fired in the blink of an eye, as can bankers (Luyendijk 2015, pp. 75-76). If, years after the fact, the sale of a faulty financial product is brought to light, then this may be bad for a bank's reputation, but who is to say that the banker responsible still works there? Third, risky and opportunistic behaviour is rewarding due to a moral hazard problem. After all, if taking a risk results in negative consequences for a bank, there are all kinds of safety nets in place (Luyendijk 2015, pp. 61-62). If it happens to a listed company, the shareholders are the ones bearing the financial risk. If it concerns a financial institution which cannot go bankrupt - a bank that is "too big to fail" - then the taxpayer will ultimately pay the price. On the other hand, a risk translating into a success is followed by a reward. In short, whereas the people taking the risks are not the ones bearing them, they do (literally) take credit for any ensuing successes. ${ }^{77}$

No Changes After the Financial Crisis In spite of the official measures and self-regulation implemented after the financial crisis, perverse incentives do not seem to have disappeared from the financial markets (Luyendijk 2015, pp. 127-129). For example, in April 2014 the chairman of the Dutch Financial Markets Authority said that the measures up until then taken by investment advisors, banks, insurers, accounting firms, and other financial institutions constituted steps in the right direction, but insufficient ones. The real transformation to "a

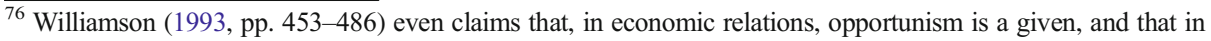
such relationships, there is no room for trust beyond calculated self-interest. According to him, trust that does go beyond that becomes blind and unconditional trust, which is not helpful and will not survive in markets. Critical of this view: Nooteboom (2002b, p. 15).

${ }^{77}$ Luyendijk (2015, pp. 98, 132) also points out the problems regarding the risk and compliance departments.
} 
culture of sincerity and honesty," with a greater emphasis on clients' interests still has to take place, according to the chairman. ${ }^{78}$ In the UK regulator's Business Plan 2015/16 (Financial Conduct Authority 2015), Financial Conduct Authority chairman John Griffith-Jones said something similar: "Poor culture and controls continue to concern us, notwithstanding the efforts being made by firms to improve both." The persistence of perverse incentives can partly be explained by the lack of feelings of guilt or shame on the part of the people working in the financial sector or, as Luyendijk (2015, p. 79) summarizes the prevailing thought among them, "have lunch or be lunch." "'Sheep get slaughtered,' I was told, and given the chance you are to 'rip your client's face off'. Others perceive stock market trading to be '[...] zero-sum: I can only win if you lose and vice versa'. 'There is a fool in every trade' is a standard expression. 'You have to know who the fool is, because if you don't, then you are the fool.'” (Luyendijk 2015 , p. 79). Therefore, the financial sector does not appear to have changed fundamentally, to have learned much from the financial crisis, or in general to admit to having done anything wrong.

For that matter, people not being good at learning from their mistakes is not unique to the financial sector. A possible explanation for this is what social psychology calls the "fundamental attribution error": people's tendency to attribute their own objectionable behaviour to situational factors (e.g., Krause and Corts 2012, pp. 567-568). ${ }^{79}$ The maintaining of selfesteem is a function and often a result of this attribution.

\section{Perverse Incentives as a Constant Factor in the Existing and Future Financial Markets: Financial Products Versus Other Consumer Goods}

So far, particular characteristics of the financial sector have prevented the described incentives from disappearing, an important one being that financial products are inherently different from other consumer goods. Comparing investing money into a financial product to buying an apple can illustrate these differences. First, when a consumer buys an apple, he or she can easily distinguish between a good apple and a bad one. With financial products, this is much harder, given their complexity and a general lack of knowledge about them on the side of consumers (e.g., Alessie et al. 2011, pp. 527-528).

A second difference is that as soon as a bite is taken out of the apple it becomes clear whether it tastes as expected. Considering the relatively long-term nature of a financial product, such as a pension product, it will only become clear after a long period of time whether it yields the expected profit. Besides, if the product fails to meet expectations, then causal ambiguity will prevent the customer from knowing why it did so ("Causal Ambiguity" section). Third, after consuming all of the apples, most consumers will buy another batch. If the apples did not taste good or if another grocer offers them at a lower price, then the consumer will most likely buy the apples there. The equivalent of "buying another batch" does not occur often in the financial markets, something which, again, is connected to the long-term nature of these

\footnotetext{
${ }_{78}$ Financial Markets Authority (2014). Even though "genuine security and fairness" could be a respectable goal, it is doubtful whether it is a realistic one. Furthermore, the chairman of the board of the Authority of the Financial Markets said that the financial sector has yet to find the right tone (Van Vugt 2015).

${ }^{79}$ While in case of objectionable behaviour of others there is a tendency to attribute this to their personal characteristics. In case of commendable behaviour, the opposite mostly happens.
} 
products. ${ }^{80}$ In view of the aforementioned characteristics, perverse incentives will usually have greater influence on the behaviour of financial institutions than their interest in having a good reputation.

\section{Trust Can Be Stimulated and Does Not Always Parallel Reliability}

"The Concept of 'Trust"” section points out that trust and reliability do not always go hand-inhand. This is underlined by several studies that show that trust is also determined by subjective factors. For instance, there are indications that having face-to-face contact with an advisor and the circumstances under which an investment decision is made have a greater effect on investors than the characteristics of the investment product in question (Monti et al. 2014, p. 1751). ${ }^{81}$ This is confirmed by a study by Monti et al. (2014, p. 1749), which concludes that communication and relational aspects are probably the most important factors determining the degree of trust a consumer is willing to put in an advisor. For instance, the quality of the communication between the customer and the advisor is considered more important than the performance and competence of the financial advisor (Monti et al. 2014, p. 1753). ${ }^{82}$ Furthermore, other studies show that we put more trust in a person who is similar to ourselves (DeBruine 2002, pp. 1307-1312). Considering the widespread presence of perverse incentives and the fact that financial institutions are commercial parties, it is not inconceivable for such insights to be used in order to increase consumer trust. Accordingly, with regard to the training of advisors, a communication course appears to be more effective when it comes to building trust than a content-focused course. Similarly, the level of trust can be increased by coupling an advisor with a customer on the basis of their similarities (Pentland 2008, p. 40). Trust can therefore be stimulated. However, if through such actions a greater degree of trust is put in, for instance, through an advisor, this will have little to do with the question of whether this trust is justified (reliability).

\section{Preventing a Chain Reaction of Distrust}

Perhaps the crisis of trust in 2008 would have been less substantial if there had been a more realistic degree of trust in the financial sector at the time. News items about opportunistic behaviour in bankers, for instance, would not thus have come as a bolt from the blue; or, to elaborate on Baier's (1986, p. 234) metaphor above: the investor would then have probably already had some trouble breathing as a result of the polluted air ${ }^{83}$ in the financial market. A more realistic and more stable level of consumer trust would possibly have resulted in a less severe chain reaction of distrust.

\footnotetext{
${ }^{80}$ In addition, it turns out that during the term of a financial product, partly in view of the complexity of such products, consumers hardly ever switch to another financial product (Springford 2011, pp. 32, 34-35).

${ }^{81}$ Monti refers to Pentland (2008) (not to a specific page number, but it most likely alludes to the contents of page 40).

82 Considering the complexity of, for instance, financial products, it is hard for consumers to assess, e.g., an advisor's expertise, which is possibly why they focus on the quality level of the communication.

${ }^{83} \mathrm{I}$ am alluding to the perverse incentives described earlier.
} 


\section{Conclusion}

The use of EU legislation to regain investor trust is a growing trend. Examination of a number of legislative proposals shows that they (1) do not clearly define "trust," and (2) they do not explain why a restoration of trust in the financial sector is a worthy goal. With regard to the first point, uncertainty surrounding the concept of trust is undesirable, since it renders a great deal of research useless as well as resulting in trust as a legislative goal being a malleable and therefore rather meaningless one.

This article has therefore attempted to make the concept of trust somewhat tangible by going into a few of its elements and characteristics. In addition, it was argued that the effectiveness of legislation when it comes to promoting consumer trust can be questioned. For instance, there are indications that the distance between the legislator and the financial sector is too small for such legislation to be effective. Furthermore, research suggests that high bonuses are the most important reason for people to lose their trust in banks. For this reason, it remains to be seen whether EU legislation can counterbalance recurring news stories about extravagant pay rises for bankers.

Finally, investor trust as a goal of legislation was discussed. In the new EU legislation, it is assumed, without offering reasons, that the restoration of trust in the financial sector is a necessary pursuit. However, it is not so much the "restoration of trust" but "the pursuit of a realistic degree of trust"-implying a certain distrust - which should be the goal of such legislation, since various perverse incentives and subjective factors play a role in the financial markets. ${ }^{84}$ Considering the complexity of the financial sector and its often intricate products, it is unlikely for such incentives to be removed by market forces. A realistic degree of trust will possibly lead to a more stable level of investor trust, which at the time of the financial crisis could have prevented a chain reaction of distrust, and could hopefully prevent one in the future. What exactly constitutes a realistic degree of trust cannot be established in absolute terms, since it depends on the subject of trust, the object of trust, the competence or intentions of the object, and the specific circumstances. ${ }^{85}$ All in all, the European legislator does not appear to be on the right track in its efforts to restore consumer trust in the financial sector. Instead, a realistic degree of trust, implying a certain distrust, could mean a step in the right direction for consumers, the financial sector, and a smoothly functioning economy!

Open Access This article is distributed under the terms of the Creative Commons Attribution 4.0 International License (http://creativecommons.org/licenses/by/4.0/), which permits unrestricted use, distribution, and reproduction in any medium, provided you give appropriate credit to the original author(s) and the source, provide a link to the Creative Commons license, and indicate if changes were made.

\section{References}

Aghion, P., Algan, Y., Cahuc, P., \& Shleifer, A. (2009). Regulation and distrust. (Working Paper No. 14648). Retrieved from National Bureau of Economic Research website: http:/www.nber.org/papers/w14648.pdf.

Alessie, R., Van Rooij, M., \& Lusardi, A. (2011). Financial literacy and retirement preparation in the Netherlands. Journal of Pension Economics and Finance, 4, 527-545.

Arrow, K. T. (1972). Gifts and exchanges. Philosophy \& Public Affairs, 1(4), 343-362.

Arrow, K. T. (1999). Observations on social capital. In P. Dasgupta \& I. Serageldin (Eds.), Social capital. A multifaceted perspective (pp. 3-5). Washington D.C.: World Bank.

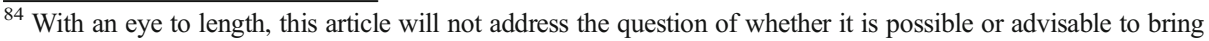
about a realistic degree of trust and, if so, which measures are suitable for this purpose.

85 Ibid.
} 
Baier, A. (1986). Trust and antitrust. Ethics, 96(2), 231-260.

Beale, H., \& Dugdale, A. (1975). Contracts between businessmen: Planning and the use of contractual remedies. British Journal of Law and Society, 2, 45-60.

Ben-Ner, A., \& Putterman, L. (2001). Trusting and trustworthiness. Boston University Law Review, 81, 523-551.

Ben-Ner, A., \& Putterman, L. (2009). Trust, communication and contracts: An experiment. Journal of Economic Behavior \& Organization, 70, 106-121.

Berg, J., Dickhaut, J., \& McCabe, K. (1995). Trust, reciprocity, and social-history. Games and Economic Behavior, 10, 122-142.

Beugelsdijk, S., \& Schaik, A. B. T. M. (2003). Participation in civil society and European regional economic growth. In W. Arts, J. Hagenaars, \& L. Halman (Eds.), The cultural diversity of European unity. Find, explorations and reflections from the European Value Study (pp. 119-145). Leiden: Brill.

Bhattacharya, R., Devinney, T. M., \& Pillutla, M. M. (1998). A formal model of trust based on outcomes. The Academy of Management Review, 3, 459-472.

BKR (The Office of Credit Registration's Mortgage Barometer). (2014). BKR Hypotheekbarometer bijna 17.000 consumenten er bij met een betalingsachterstand op de hypotheek. [The Office of Credit Registration's Mortgage Barometer: An increase of almost 17.000 consumers with mortgage payment difficulties]. Retrieved from: http://perskamer.bkr.nl/bkr-hypotheekbarometer-bijna-17000-consumenten-er-bij-met-eenbetalingsachterstand-op-de-hypotheek.

BKR (The Office of Credit Registration's Mortgage Barometer). (2015). Aantal betalingsproblemen op hypotheek neemt licht af. [Slight decrease of Mortgage payment difficulties]. Retrieved from: https:/www.bkr.nl/nieuws-en-berichten/aantal-betalingsproblemen-op-hypotheek-neemt-licht-af/.

Blau, P. M. (1964). Exchange and power in social life. New York: Wiley.

Bohnet, I., Frey, B. S., \& Huck, S. (2001). More order with less law: On contract enforcement, trust, and crowding. American Political Science Review, 95, 131-144.

Bol, M., Van Esterik-Plasmeijer, P. \& Van Raaij, W.F. (2014). Hoe kunnen verzekeraars het vertrouwen herstellen? ('How can insurers restore trust?'). AM AssurantieMagazine, 48-50.

Bottazzi, L., Da Rin, M., \& Hellmann, T. (2016). The importance of trust for investment: Evidence from venture capital. The Review of Financial Studies, 29(9), 2283-2318.

Brown, G. (2009). How can we restore trust in financial institutions. The Financial Times. Retrieved from http://www.ft.com.

Butler, J., Giuliano, P., \& Guiso, L. (2009). The right amount of trust. (Working Paper No. 15344). Retrieved from National Bureau of Economic Research website: http://www.nber.org/papers/w15344.

Carlin, B. I., Dorobantu, F., \& Viswanathan, S. (2009). Public trust, the law, and financial investment. Journal of Financial Economics, 92, 321-341.

Casson, M., \& Giusta, M. D. (2006). The economics of trust. In R. Bachmann \& A. Zaheer (Eds.), Handbook of trust research (pp. 332-354). Cheltenham: Edward Elgar.

Chater, N., \& Decision Technology Limited. (2015). Mind the gap: Restoring consumer trust in financial services. Prepared for the Financial Services Compensation Scheme. Retrieved from http://www.fscs.org.uk.

Chowdhury, P. P. (2012). Antecedents and consequences of trust and commitment in B2B relationship: A review of literature. Indore Management Journal, 4, 49-63.

Collins, H. (2002). Regulating contracts. Oxford: Oxford University Press.

De Jager, C. E. (2015). Who are you, investor: Mr. Spock, Captain Kirk or somewhere in between? A behavioural finance exploration and suggestions for better informing investors about complex investment products through information disclosure. In I. Samoy \& M. B. M. Loos (Eds.), Information and notification duties (pp. 101-121), Cambridge: Intersentia International Law Series.

Deakin, S. (2006). Learning about contracts: Trust, cooperation and contract law. In R. Bachmann \& A. Zaheer (Eds.), Handbook of trust research (pp. 218-232). Cheltenham: Edward Elgar.

DeBruine, L. M. (2002). Facial resemblance enhances trust. Proceedings of the Royal Society of London B, 269, 1307-1312.

Deutsch, A., \& Neely, J. (2014). Dutch bank ABN Amro boosts salaries after bonus cap-Report. Reuters. Retrieved from http://www.reuters.com/article/netherlands-abnamro-bonuses-idUSL5N0OZ1AY20140618.

Diamond, D. W., \& Dybvig, P. H. (1983). Bank runs, deposit insurance, and liquidity. The Journal of Political Economy, 91(3), 401-419.

Dijsselbloem, J. R. V. A. (2015). Banken, stop die lobby anders komt 2008 terug [Banks, Stop the lobby otherwise 2008 comes back]. NRC.

Dincer, O. C., \& Uslaner, E. M. (2010). Trust and growth. Public Choice, 142, 59-67.

Dunn, J. (2000) 'Trust and political agency'. In D. Gambetta (Ed.) Trust: Making and breaking cooperative relations (pp. 73-93). Electronic edition, Department of Sociology, University of Oxford, retrieved from http://citeseerx.ist.psu.edu/viewdoc/download?doi=10.1.1.22.5232\&rep=rep1\&type=pdf. 
Eckel, C. C., \& Wilson, R. K. (2004). Is trust a risky decision? Journal of Economic Behavior \& Organization, $55,447-465$.

Engle-Warnick, J., \& Slonim, R. L. (2004). The evolution of strategies in a repeated trust game. Journal of Economic Behavior \& Organization, 55, 553-573.

European Commission. (2012). Commission Staff Working Document. Executive Summary of the Impact Assessment. Accompanying the document Proposal for a Regulation of the European Parliament and of the Council of Key information documents for investment products (SWD(2012) 188 final C70179/12). Strasbourg. Retrieved from: http://eur-lex.europa.eu/legal-content/EN/TXT/PDF/?uri=CELEX:52012 $\mathrm{SC} 0188 \&$ from $=\mathrm{EN}$.

European Securities and Markets Authority. (2012). Restoring investors' trust in Europe's markets. BBA Annual Conference, London, retrieved from https://www.esma.europa.eu/sites/default/files/library/2015/11/2012675.pdf.

Evans, A. M., \& Krueger, J. I. (2009). The psychology (and economics) of trust. Social and Personality Psychology Compass, 3(6), 1003-1017.

Fehr, E. (2009). On the economics and biology of trust. Journal of the European Economic Association, 7, 235266.

Fehr, E., \& Rockenbach, B. (2003). Detrimental effects of sanctions on human altruism. Nature, 442, 137-140.

Financial Conduct Authority. (2015). Business Plan 2015/16. Retrieved from the Financial Conduct Authority website http://www.fca.org.uk/static/channel-page/business-plan/business-plan-2015-16.html.

Financial Markets Authority. (2014). Annual Report 2013: Eerlijkheid en veiligheid grootste uitdaging financiële sector [Honesty and safety biggest challenge for the financial sector]. Retrieved from www.afm.nl.

Gärling, T., Kirchler, E., Lewis, A., \& Van Raaij, W. F. (2010). Psychology, financial decision making, and financial crises. Psychological Science in the Public Interest, 10(1), 1-47.

Georgarakos, D., \& Pasini, G. (2011). Trust, sociability, and stock market participation. Review of Finance, 15, 693-725.

Glaeser, E., et al. (2000). Measuring trust. The Quarterly Journal of Economics, 115, 811-846.

Göran, P., \& Hägg, T. (1994). The economics of trust, trust-sensitive contracts, and regulation. International Review of Law and Economics, 14, 437-451.

Guiso, L. (2010). A Trust-driven financial crisis. Implications for the future of financial markets (Working Paper No. 06/10). Retrieved from Einaudi Institute for Economics and Finance website: http://www.eief. it/files/2012/09/wp-06-a-trust-driven-financial-crisis-implications-for-the-future-of-financial-markets.pdf

Guiso, L., Sapienza, P., \& Zingales, L. (2004). The role of social capital in financial development. American Economic Review, 94, 526-556.

Guiso, L., Sapienza, P., \& Zingales, L. (2008). Trusting the stock market. Journal of Finance, 63(6), 2557-2600.

Hargreaves, D. (2007). Rock bottom-That's where trust in financial services is. The Guardian. Retrieved from http://www.theguardian.com.

Helliwell, J. F. (1996). Economic growth and social capital in Asia (NBER Working Paper 5470). Retrieved from NBER.

Helliwell, J. F., \& Wang, S. (2010). Trust and well-being (Working Paper No. 15911). Retrieved from National Bureau of Economic Research website: http://www.nber.org/papers/w15911.pdf.

Heymann, J., \& Ariely, D. (2004). Effort for payment: A tale of two markets. Psychological Science, 15, 787793.

Hoogerwerf, A. (1990). Reconstructing policy theory. Evaluation and Program Planning, 13, 285-291.

Jansen, D.-J., Mosch, R. H. J., \& Van der Cruijsen, C. A. B. (2015). When does the general public lose trust in banks? Journal of Financial Services Research, 48, 127-141.

Jones, G. R., \& George, J. M. (1998). The experience and evolution of trust: Implications for cooperation and teamwork. The Academy of Management Review, 23(3), 531-546.

Katona, G. (1975). Psychological economics. New York: Elsevier.

Knack, S. (2001). Trust, associational lie and economic performance. In J. F. Helliwell \& A. Bonikowska (Eds.), The contribution of human and social capital to sustained economic growth and well-being (pp. 172-202). Ottawa: HRDC and OECD.

Knack, S., \& Keefer, P. (1997). Does social capital have an economic payoff? A cross-country investigation. Quarterly Journal of Economics, 112(4), 1251-1288.

Knee, H. W., \& Knox, R. E. (1970). Conceptual and methodological considerations in the study of trust. Journal of Conflict Resolution, 14, 357-366.

Kosovetsky, L. (2016). Whom do you trust? Investor-advisor relationships and mutual fund flows. The Review of Financial Studies, 29(4), 898-936.

Krause, M. A., \& Corts, D. P. (2012). Psychological science. Boston: Pearson.

Lewis, J. D., \& Weigert, A. (1985). Trust as a social reality. Social Forces, 4, 967-985. 
Liebsch, B. (2010). Violated trust and the self: a negativistic approach. In A. Gron \& C. Welz (Eds.), Trust, sociality, selfhood (pp. 173-191). Tübingen: Mohr Siebeck.

Luhmann, N. (1979). Trust and power. Chichester: John Wiley \& Sons.

Luyendijk, J. (2015). Swimming with sharks. My journey into the world of the bankers. London: Guardian Books and Faber \& Faber.

Maas, C., Eijffinger, S., Van den Goorbergh, W., De Swaan, T., \& Weitjens, J. (2009). Naar herstel van vertrouwen. [To recovery of trust]. Retrieved from NVB website: www.nvb.nl.

Macaulay, S. (1963). Non-contractual relations in business: A preliminary study. American Sociological Review, 28, 55-67.

Maijoor, S. (2012). Restoring investors' trust in Europe's markets. In BBA Annual Conference 2012. London. Retrieved from the ESMA website: https://www.esma.europa.eu/sites/default/files/library/2015/11/2012675.pdf

Mak, V. (2015). What is responsible lending? The EU consumer mortgage credit directive in the UK and the Netherlands. Journal of Consumer Policy, 38, 411-430.

Malhotra, D., \& Murnighan, K. J. (2002). The effects of contracts on interpersonal trust. Administrative Science Quarterly, 47, 534-559.

Mayer, R. C., Davis, J. H., \& Schoorman, F. D. (1995). An integrative model of organizational trust. The Academy of Management Review, 3, 709-734.

Meuwese, A. C. M. (2008). Impact assessment in EU lawmaking. The Hague: Kluwer Law International.

Moloney, N. (2005). Building a retail investment culture through law: The 2004 markets in financial instruments directive. European Business Organization Law Review, 6(3), 341-421.

Monaghan, A. (2013). Barclays boss admits it could take 10 years to rebuild public trust. The Guardian. Retrieved from http://www.theguardian.com.

Monti, M., Pelligra, V., Martignon, L., \& Berg, N. (2014). Retail investors and financial advisors: New evidence on trust and advice taking heuristics. Journal of Business Research, 67, 1749-1757.

Mosch, R. H. J., \& Prast, H. M. (2008). Confidence and trust: Empirical investigations for the Netherlands and the financial sector. DNB Occasional Studies, 6(2).

Mulder, L., Van Dijk, E., De Cremer, D., \& Wilke, H. A. M. (2006). Undermining trust and cooperation: The paradox of sanctioning systems in social dilemmas. Journal of Experimental Social Psychology, 42, 147-162.

Nooteboom, B. (2002a). Trust. Forms, foundations, functions, failures and figures. Cheltenham: Edward Elgar.

Nooteboom, B. (2002b). Vertrouwen. Vormen, grondslagen, gebruiken en gebreken van vertrouwen [Trust. Forms, foundations, functions, and failures]. Schoonhoven: Academic Service.

Nooteboom, B. (2006). Forms, sources and processes of trust. In R. Bachmann \& A. Zaheer (Eds.), Handbook of trust research (pp. 247-263). Cheltenham: Edward Elgar.

Nooteboom, B. (2009). Vertrouwen: Betekenis, bronnen en beperkingen [Trust: meaning, sources, and limitations]. In P. van Schilfgaarde \& B. Nooteboom (Eds.), Vertrouwen ('Trust) (pp. 31-55). Amsterdam: Aksant Academic Publishers.

Nooteboom, B. (2010). Vertrouwen, besluitvorming en communicatie [Trust, decision-making, and communication]. $M \& O, 6,25-38$.

O’Neill, O. (2013). What we don't understand about trust, TEDx. Retrieved from: http://www.ted. com/talks/onora o neill what we don $\mathrm{t}$ understand about trust.

Omarova, S. T. (2010). Rethinking the future of self-regulation in the financial industry (Cornell Law Faculty Publications Paper 1022). Retrieved from the Cornell University Law Library: http://scholarship.law.cornell. edu/cgi/viewcontent.cgi?article $=2489 \&$ context=facpub.

Pentland, A. S. (2008). Honest signals. How they shape our world. Cambridge: Massachusetts Institute of Technology.

Peperzak, A. T. (2013). Trust. Who or what might support us? New York: Fordham University Press.

Pinotti, P. (2008). Trust, honesty and regulation (MRRA paper 7740).

Pirson, M., \& Malhotra, D. (2008). Unconventional insights for managing stakeholder trust. MIT Sloan Management Review, 4, 43-50.

Prast, H., Mosch, R., \& Van Raaij, W. F. (2005). Vertrouwen, Cement van de Samenleving en Aanjager van de Economie. [Trust, cement of the society and driver of the economy]. Amsterdam: De Nederlandsche Bank.

Rawlings, P., Georgosouli, A., \& Russo, C. (2014). Regulation of financial services: Aims and methods, Queen Mary University of London, Centre for Commercial Law Studies, retrieved from: http://www.ccls.qmul.ac. uk/docs/research/138683.pdf.

Reich, R. (2008). Government needs to rebuild trust in markets. U.S. News \& World Report. Retrieved from the website http://www.usnews.com.

Rotter, J. B. (1967). A new scale for measurement of interpersonal trust. Journal of Personality, 35(651), 665.

Sapienza, P., \& Zingales, L. (2012). A trust crisis. International Review of Finance, 12(2), 123-131. 
Simpson, B., \& Eriksson, K. (2009). The dynamics of contracts and generalized trustworthiness. Rationality and Society, 21(1), 59-80.

Six, F. (2003). The dynamics of trust and trouble. In B. Nooteboom \& F. Six (Eds.), The trust process in organizations. Empirical studies of the determinants and the process of trust development (pp. 196-222). Cheltenham: Edward Elgar.

Sobel, J. (2002). Can we trust social capital? Journal of Economic Literature, 40, 139-154.

Springford, J. (2011). A confidence crisis. Restoring trust in financial services. London: The Social Market Foundation.

Stiglitz, J. E. (2008). The fruit of hypocrisy. The Guardian. Retrieved from: http://www.theguardian. com/commentisfree/2008/sep/16/economics.wallstreet.

Temple, J., \& Johnson, P. (1998). Social capability and economic growth. The Quarterly Journal of Economics, 113(3), 965-990.

The Dutch Financial Markets Authority. (2011). Toezicht op productontwikkeling noodzakelijk [Oversight of product development necessary]. Retrieved from the website http://vnab.nl.

The Social Market Foundation. (2011). In J Springford (Ed.), A confidence crisis? Restoring trust in financial services. London: SMF. Retrieved from http://www.smf.co.uk.

Tonkiss, F. (2009). Trust, confidence and economic crisis. Intereconomics, 44(4), 196-202.

Trotman, A. (2015). Banks must 'raise their game' to win back public trust. The Telegraph. Retrieved from http://www.telegraph.co.uk.

Van der Cruijsen, C., De Haan, J., \& Jansen, D. (2013). Trust and financial crisis experiences (Working Paper no. 389). Retrieved from DNB website: http:/www.dnb.nl/binaries/working\%20Paper\%20389_tcm46-295960. pdf.

Van Esterik-Plasmeijer P. W. J., \& Van Raaij, W. F. (2012). Components of trust in financial institutions. A comparison of Greece, Russia, The Netherlands, and Turkey. Retrieved from the website: http://www. behavioralfinanceinsights.com/downloads/components-of-trust-in-financial-institutions.pdf.

Van Raaij, W. F. (2009). Hoe krijgt de financiële sector het vertrouwen weer terug? [How can the financial sector restore trust?]. MeJudice. Retrieved from the MeJudice website: http://www.mejudice.nl/artikelen/detail/hoekrijgt-de-financiele-sector-het-vertrouwen-weer-terug.

Van Vugt, T. (2015). 15 vragen aan de bestuursvoorzitter van de AFM: 'Financiële sector heeft juiste toon nog niet gevonden' [15 questions for the chairman of the board of the Authority Financial Markets: 'Financial sector has yet to find the right tone]. Amweb, retrieved from the website: http://amweb.nl/branche-724322/15-vragen-aan-de-bestuursvoorzitter-van-de-afm-financiele-sectorheeft-juiste-toon-nog-niet-gevonden.

Vohs, K. D., Mead, N. L., \& Goode, M. R. (2006). The psychological consequences of money. Science, 314, 1154-1156.

Voortman, P. M. (2012). Vertrouwen werkt. Over werken aan vertrouwen in organisaties [Trust works: working on trust in organisations]. Amsterdam: Trustworks.

Wallace, T. (2015). Bankers' bonus cap drives up salaries, says Bank of England. The Telegraph. Retrieved from http://www.telegraph.co.uk/finance/bank-of-england/12052055/Bankers-bonus-cap-drives-up-salaries-saysBank-of-England.html.

Westerman, P. C. (2007). Governing by goals: Governance as a legal style. Legisprudence, 1(1), 51-72.

Westerman, P. C. (2008). Normering via doelstelling: Zorgplichten. [Standardisation by means of objective: care duties]. In P. C. Westerman \& A. R. Mackor (Eds.), Vormen van (de?)regulering (pp. 51-72). The Hague: Boom Juridische Uitgevers.

Westerman, P. C. (2010). Who is regulating the self? Self-regulation as outsourced rule-making. Legisprudence, 4(3), 225-241.

Westerman, P. C. (2014). De verleiding van doelregulering. [The temptation of goal-regulation]. In S. C. Loeffen, S. A. J. Munneke, A. R. Neerhof, \& A. E. Schilder (Eds.), Integriteit in politiek en bestuur (pp. 37-44). Oisterwijk: Wolf Legal Publishers.

Williams, B. (1988). Formal structures and social reality. In D. Gambetta (Ed.), Trust: making and breaking of cooperative relations (pp. 3-13). Oxford: Blackwell.

Williamson, O. E. (1993). Calculativeness, trust and economic organization. Journal of Law and Economics, 36, $453-486$.

Zak, P. J., \& Knack, S. (2001). Trust and growth. The Economic Journal, 111, 295-321.

Zhong, S., Monakhov, M., Mok, H.P., Tong, T., Lai, P. S., Chew, S. H., et al. (2012). U-shaped relation between plasma oxytocin levels and behavior in the trust game. PLOS One, 7(12), e51095: Retrieved from: http://journals.plos.org/plosone/article/asset?id=10.1371/journal.pone.0051095.PDF.

Zingales, L. (2011). The role of trust in the 2008 financial crisis. The Review of Austrian Economics, 24(3), 235249. 